\title{
ATEB B
}

Dinî Araștırmalar Dergisi Journal for Religious Studies e-ISSN: $2757-5616$

ATEBE Dergisi / Journal of ATEBE

Sayı: 6 (Aralık / December 2021), 175-191.

\section{İbrahim Aczî Kendi Bibliyografyası}

\author{
Bibliography of Ibrahim Aczi Kendi
}

\author{
Muhammet Akif Tiyek \\ Araştırma Görevlisi, Ankara Üniversitesi, Türk İslam Edebiyatı Anabilim Dalı \\ Research Assistant, Ankara University, Department of Turkish Islamic Literature \\ Ankara, Turkey \\ m.akiftiyek@hotmail.com \\ orcid.org/ 0000-0002-4975-6664 \\ https://ror.org/01wntqw50
}

\section{Makale Bilgisi / Article Information}

Makale Türü / Article Types: Bibliyografi / Bibliography

Geliş Tarihi / Date Received: 14 Kasım/November 2021

Kabul Tarihi / Date Accepted: 19 Aralı/December 2021

Yayın Tarihi / Date Published: 31 Aralı/December 2021

Yayın Sezonu / Pub Date Season: Aralı/December

Atıf / Cite as: Tiyek. Muhammet Akif. “İbrahim Aczî Kendi Bibliyografyası”. ATEBE 6 (Aralık 2021), 175191. https://doi.org/10.51575/atebe.1023317

İntihal / Plagiarism: Bu makale, iTenticate yazılımınca taranmıştır. İntihal tespit edilmemiştir/This article hasbeen scanned by iTenticate. No plagiarism detected.

Etik Beyan/Ethical Statement: Bu çalışmanın hazırlanma sürecinde bilimsel ve etik ilkelere uyulduğu ve yararlanılan tüm çalışmaların kaynakçada belirtildiği beyan olunur/It is declared that scientific and ethical principles have been followed while carrying out and writing this study and that all the sources used have been properly cited (Muhammet Akif Tiyek).

Yayıncı / Published by: Ankara Sosyal Bilimler Üniversitesi / Social Sciences University of Ankara. Bu makale Creative Commons Alıntı-GayriTicariTüretilemez 4.0 (CC BY-NC 4.0) Uluslararası Lisansı altında lisanslanmıștır. This article is an open access article distributed under the terms and conditions of the Creative Commons Attribution-NonCommercial-NoDerivatives 4.0 (CC BY-NC 4.0) International License. 


\title{
İbrahim Aczî Kendi Bibliyografyası*
}

\section{$\ddot{0} \mathbf{z}$}

İbrahim Aczî Kendi, 1882-1965 yılları arasında yaşamış, iyi bir eğitim almış, devlet kadrolarında memurluk, müdürlük ve öğretmenlik gibi birçok görevlerde bulunmuştur. Aczî 1936 yılında, 34 yıl süren hizmetinin ardından, emekliye ayrılarak kendisini kültürel değerlerin araştırılmasına ve bu değerlerin gelecek nesillere aktarılmasına adamıștır. Hayatının son demlerine değin bu ülkü uğrunda çok gayret sarf etmiş ve bu çerçevede birçok eser kaleme almıștır. Eserlerinde özellikle Mevlânâ Celâleddîn-i Rûmîye (öl. 672/1273) özel bir önem verdiği ve çalışmalarını onun Mesnevî adlı eseri üzerine yoğunlaştırdığı görülmektedir. Kendisinin ve önemli bazı tarihî şahsiyetlerin hayatını konu edinmiş olan Aczî, eserlerinde muasır bazı yazarlara ve onların çalışmalarına yönelik eleştirilere de yer vermiştir. Ayrıca Türkçe, Arapça ve Farsça şiirler kaleme almıştır. O, toplumun içinde bulunduğu koşulları, gelenek ve görenekleri araștırmalarda bulunduğu, görev yaptığı yerler çerçevesinde ortaya koymuş; on dokuzuncu ve yirminci yüzyılda meydana gelen değișim ve dönüșüm hareketlerine bizâtihi şahit olmuş ve bu olaylar karşısında kendi düşüncesini ifade etmekten geri durmamıştır. İbrahim Aczî, çocukluk döneminden itibaren duygularını şiirleri aracılığıyla ifade etmiş, genç neslin Türk kültür ve değerlerini unutmaması için elinden geldiğince genç kuşakları kültürel değerlerle tanıştırmaya gayret etmiştir. Bu çerçeveden bakıldığında Aczî’nin kendisine önemli bir misyon edindiği söylenebilir. Folklor alanına katkı sağlamış, döneminin panoramasını yansıtmak suretiyle de bulunduğu coğrafyaya ilișkin önemli veriler sunmuştur. Aczî hakkında günümüze kadar yapılan çalışmalarda onun hayatı ve eserlerine yüzeysel bir șekilde değinildiği, hatta bu çalıșmalardaki bilgilerin birbirlerinin tekrarı olduğu tespit edilmiștir. Yaptığı çalışmalarda İbrahim Aczî'nin kısmen de olsa bibliyografyasına yer veren ilk isim Cahit Öztelli'dir. Daha sonra Mehmet Ali Uz, Öztelli'nin tespit ettiği bibliyografyaya birkaç eser daha eklemek suretiyle yeni bir yazı kaleme almıștır. Öztelli ve Uz tarafından ortaya konulan bu araștırmalar, kendilerinden sonra yapılan diğer çalışmalara örnek teşkil etmiş, hatta bazıları tarafından aynıyla tekrarlanmıștır. Ancak söz konusu çalışmalar da İbrahim Aczî’nin bibliyografyasını tam anlamıyla yansıtmamaktadır. Bu yönüyle çalışmamız, bibliyografyasında eksiklik olduğu tespit edilen İbrahim Aczî Kendi ile ilgili literatür taraması yapmayı ve onun kapsamlı bir bibliyografyasını ortaya koymayı amaçlamaktadır. Makalenin giriș kısmında İbrahim Aczî̀nin bibliyografyasına ilişkin yapılan çalıșmalar değerlendirilmiş, onun hayatı ile ilgili kısaca bilgi verilmiş ve sonraki bölümde Aczînnin tespit edilen bibliyografyası sunulmuştur. Böylece Aczî̀nin eserleri, çeșitli gazete ve dergilerde yer alan tefrika ve makaleleri ile diğer yazarlar tarafından onun hayatı ve eserleri ile ilgili yapılan çalışmalar ortaya konmaya çalışılmıştır.

Anahtar Kelimeler: Halk Edebiyatı, Türk İslam Edebiyatı, İbrahim Aczî Kendi, Aczî, Bibliyografya.

\section{Bibliography of Ibrahim Aczi Kendi}

\begin{abstract}
Ibrahim Aczî Kendi lived between 1882-1965, received a good education, and held many government positions such as civil servant, director and teacher. He retired in 1936, after 34 years of service, and devoted himself to researching cultural values and transferring these values to future generations. Until the last moments of his life, he wrote many works in this framework. In his works, he gave special importance to Mawlânâ Jalâl al-Dîn Rûmî (d. 672/1273) and focused on Rumi's famous book, Mathnawî. Aczî, who dealt with lives of himself and some important historical figures, also included critics of some contemporary writers and their works in his books. Besides, he has his own Turkish, Arabic and Persian poems. He did not only present the conditions, traditions and customs of the society, but also gave his opinion to the change and transformation movements that took place in the nineteenth and twentieth centuries, without any, hesitation. Since his childhood, Ibrahim Aczî had expressed his feelings through his poems and tried to introduce the cultural values to the young generation with the aim of that the younger generations do not forget Turkish culture and values. He contributed to the field of folklore, and presented some important data for the geographical realm he lives in by reflecting the panorama of his life period. In the studies carried out on Ibrahim Aczî his life and works are described superficially; and the information in these studies is a repetition of each other. Cahit Öztelli is the first person to include Ibrahim Aczî's bibliography, in his works. Later, Mehmet Ali Uz wrote a new article by adding a few more works to the bibliography written by Öztelli. Although Öztelli and Uz's studies set an example for other
\end{abstract}

* Bu makale Prof. Dr. Zülfikar Güngör danışmanlığında hazırlanmakta olan “İbrahim Aczî Kendi Hayatı, Eserleri ve Dîvân'ı (İnceleme-Metin)” adlı doktora çalışmasından üretilmiștir. 
studies made after them these studies and follow up studies do not fully reflect Ibrahim Aczî's bibliography. In this respect, our study aims to search the literature about Ibrahim Aczî Kendi and to present a comprehensive bibliography of him. In the introduction part of the article, the studies on Ibrahim Aczî's bibliography were evaluated and, brief information about his life was given. The bibliography of Aczî was presented in the next section. Thus, in this study, Aczî̀s serially published works, alongside the studies made by other authors about his life and works have been tried to be analysed.

Keywords: Folk Literature, Turkish-Islamic Literature, Ibrahim Aczî Kendi, Aczî, Bibliography.

\section{Giriş}

Şair, ressam ve yazar olan İbrahim Aczî Kendi, üretken ve yayın yapmaya çok önem veren bir şahsiyettir. İbrahim Aczî, doğumundan vefatına kadar olan süreçte ardında birçok eser bırakmıștır. Aczî’nin eserleri vasiyeti üzerine ailesi tarafından Konya Yusuf Ağa Kütüphanesine bağışlanmıştır. Yusuf Ağa Kütüphanesinde İbrahim Aczî Kendi adına özel bir koleksiyon bulunmaktadır. Aczî, hayatını adeta kültür ve folklora adamış; hayatının son anlarına değin yayın faaliyetlerine ara vermemiștir. Yusuf Ağa Kütüphanesinde yazma (rika hattı ile kaleme alınan), Latin alfabesi (kendi el yazısı ile) ve matbu eserlerinin yanında özellikle yayın hayatını Konya'da sürdüren çeşitli gazete ve dergilerde olmak üzere yayınlanan birçok tefrika ve makalesi bulunmaktadır.

Aczî, eserlerinde döneminin kültürel ögelerini yansıtmış; Türk kültürünün gelecek nesillere aktarılmasında ve unutulmaya yüz tutan birtakım bilgilerin yeniden gün yüzüne çıkarılmasında önemli rol üstlenmiştir.

Bibliyografyalar, belirli bir eser, kişi veya konuyla ilgili yazılanların toplu bir şekilde sunulduğu çalışmalardır. Bu çalışmalar, kaynakların tespitinde ve araştırmacıların ana kaynağa ulaşmasında önemli bir rol üstlenmektedir. Araştırma yapılan ya da yapılacak olan konu ile ilgili çalışmaları derli toplu bir şekilde sunması, ilgili konuda çalışma yapacaklara konunun sınırlarını çizerek tanıtması ve kendisinden sonra yapılacak olan çalışmalara malzeme teşkil etmesi bibliyografyaların araştırmacılara sağladığı önemli katkılardan bazılarıdır. Bu çerçeveden bakıldığında Aczî’nin bibliyografyasının ortaya konması daha sonra yapılacak olan diğer çalışmalar için önemli bir kaynak konumunda olacağı düşünülmektedir.

İbrahim Aczî’nin yalnızca bibliyografyasını ele alan herhangi bir çalışma bulunmamaktadır. Onun hayatı ve eserleri ile ilgili yapılan çalışmalarda bibliyografyası bazı çalışmalarda hiç yer almamakta bazılarında ise aynen tekrarlanmaktadır. Ahmet Cenap Kendi ${ }^{1}$, Ahmet Çelik ${ }^{2}$, Veli Sabri Uyar ${ }^{3}$ ve İsmail Hakkl Aksoyak ${ }^{4}$ ilgili çalışmalarında Aczî̀nin bibliyografyasına yer vermemiștir. Cahit Öztelli, Aczî hayatta iken yapmış olduğu çalışmada Aczî̀nin 4'ü basılmıș (Âşsı Şem'î Konuşuyor, Mevlânâ ve Ruh-ı Mesnevî, Tercümeler ve Fikirler, Hayal Bahçesi) 17'si basılmamış (Cengiz, Ravzatü'l-Uşşâk, Hazîne-i Eș'ar, Hazret-i Hüseyin'in Şehadeti, Hazret-i Ali'nin Şehadeti, Hâtıratım ve Hayal

1 Ahmet Cenap Kendi, “Ölümünün 10. cu Yılında Şair İbrahim Aczi Kendi”, Yeni Konya (9 Ağustos 1975), 2; Ahmet Cenap Kendi, “Ölümünün 15. Yılında İbrahim Aczi Kendi Şair ve Edip, Hayatı ve Eserleri”, Yeni Konya (5 Haziran 1979), 2.

2 Ahmet Çelik, "Konya'da Okul Anıları-I İbrahim Aczi'nin Okul Anıları”, Merhaba Gazetesi Akademik Sayfalar Vefatının 50. Yılında İbrahim Aczi Kendi (1883-1965) Özel Sayı 15/18 (Haziran 2015), 277-288.

3 Veli Sabri Uyar, "Hattatlar Armağanı”, Konya Halkevi Aylık Kültür Dergisi/123-124 (Ocak-Şubat 1949), 27-33.

4 İsmail Hakkı Aksoyak, "Taşrada Değerli Bir Kültür Adamı: İbrahim Aczî Kendi”, Prof. Dr. Mehmet Arslan'a Armağan. Editör H. İbrahim Delice vd. (Sivas: Cumhuriyet Üniversitesi Yayınları, 2019), 199204.

https://dergipark.org.tr/tr/pub/atebe 
Bahçesi, Muhit ve Çocuk Ruhu, Dünya Güzelleri, Şair Nedim, Erenler Meydanı, Ömer Hayyam, Âşık Dertli, Türk Şair ve Âşskları, Konya Eski Eserler ve Kitabeleri, Șair Ayaşlı Şakir Bey, Folklor Âlemi, Divan-ı Aczî) 21 eserini tespit etmiștir. ${ }^{5}$ Öz Demokrat Konya ve Seyit Küçükbezirci Öztelli'nin verdiği bibliyografyayı aynen tekrar etmiştir.6 Daha sonra yapılan çalışmada Mehmet Ali Uz, yukarıda belirtilen Aczî̀nin basılan eserlerine 2 çalışma (Konya Mezar Folkloru ve Uyan Ey Türk Hanımı) ve 11 makale ("Cönkler, Şairler ve Âșlklar", "Âşık Hikmetî", "Așk ve Mevlânâ Celâleddin Rûmî", "Konya Halk Şairleri: Şair Rasih", "Konya Halk Şairleri: Âșık Kul Ahmet", "Konyalı Hasibe Ana”, "Âşık Dertli Konya'da", "Türk Mızrabı: Güzellik, Güzeller ve Âșıklar", "Mevlânâ ve Divan-ı Kebir", "Tenkit Nedir", "Hazire Kelimesi Üzerine") eklemiş; Öztelli'nin tespitinde yer alan "Konya Eski Eserler ve Kitabeleri" adlı çalışmaya yer vermemiştir.7 Yalçın Dikilitaş ve Serdar Ceylan, Mehmet Ali Uz'un tespit ettiği bilgileri aynen tekrar etmiştir. ${ }^{8}$ Aczî’nin oğlu Ahmet Cenap Kendi ise yaptığı başka bir çalışmada babasının basılan eserinden yalnızca 6'sına (Hayal Bahçesi, Tercümeler ve Fikirler, Hazret-i Mevlânâ, Hayyam ve Eserleri, Mezar Folkloru, Âşı Şem'î Konuşuyor) yer vermiştir.9 Söz konusu çalışmalarda en geniş bibliyografya önce Cahit Öztelli, daha sonra ilavelerle birlikte Mehmet Ali Uz tarafından kaleme alınmış ve bu yazarların verdiği bilgiler tekrar edilmiștir. Ancak Aczî'nin yukarıda belirtilen yazılardan çok daha fazlası tarafımızca tespit edilmiş olup ilgili yazıların künye bilgileri verilmiştir. Bu yönüyle bakıldığında çalışmamızın İbrahim Aczî bibliyografyası ile ilgili bu boşluğu dolduracağı düşünülmektedir.

İbrahim Aczî̀nin bibliyografyasını tespit etmek amacıyla öncelikle Yusuf Ağa Kütüphanesindeki İbrahim Aczî Kendi bölümü taranmıștır. Aczî’nin hayatı ile ilgili yapılan çalışmalar ve Yusuf Ağa Kütüphanesinde ulaşılan bilgiler ıșığında Aczî̀nin gazete ve dergilerde yer alan yazılarını tespit etmek amacıyla Ankara Milli Kütüphanede bulunan Anadolu (1964 SC 10) 10, Anadolu-Manşet (1999 SC 23), Babalık (1956 ALF B1-1962 SB 1521962 SC 55), Ekekon (1976 SC 82), Folklor Postasl (1957 SB 118), Ișlk (1959 SC 31), Konya Halkevi (1961 SB 25), Öz Demokrat Konya (1958 SÇ 19), Sabah (1960 SÇ 69), Şehir Postası (1962 SC 45), Yeni Konya (200 ALF Y745), Yeni Meram (200 ALF Y744) gibi gazete ve dergiler taranmıştır. Ayrıca vefatından sonra İbrahim Aczî ile ilgili hangi çalışmaların kaleme alındığına yönelik araştırmalar yapılmıştır.

\section{Hayatı}

İbrahim Aczî Kendi, hicrî 1299/milâdî 1882 yılında Konya Piri Mehmet Paşa Mahallesi'nde doğmuştur. Dedesi saray kurşuncubașısı olarak görev yapan ve Konya'ya sürgün edilen Edhem Efendi'dir. Babası Mahmud Efendi (öl. 1899), annesi ise Emine

5 Cahit Öztelli, "Folklorcularımız: İbrahim Aczi Kendi”, Türk Folklor Araştırmaları Dergisi 5/104 (Mart 1958), 1659.

6 Öz Demokrat Konya, "Folklorcularımız İbrahim Aczi Kendi”, (14 Mayıs 1958), 2; Seyit Küçükbezirci, “Unutulmayacak Konyalılar Konya'nın Basın, Sanat, Kültür Adamları”, Yeni Meram (11 Mart 1982), 1, 5.

7 Mehmet Ali Uz, Konya Kültürüne Hizmet Edenler (Konya: Konya Büyükşehir Belediyesi Kültür Yayınları No 48, 2003), 44-45.

8 Yalçın Dikilitaş, "İbrahim Aczi Kendi”, Anadolu Manşet Gazetesi Kültür\&Sanat (5 Ağustos 2004), 2; Serdar Ceylan, "İbrahim Aczi Kendi (1883-1965)", Merhaba Gazetesi Akademik Sayfalar Vefatının 50. Yllinda İbrahim Aczi Kendi (1883-1965) 15/18 (Haziran 2015), 277.

9 Ahmet Cenap Kendi, "Babam İbrahim Aczi Kendi", Memleket Gazetesi (30 May1s 2018). https://www.memleket.com.tr/babam-ibrahim-Aczî-kendi-25755yy.htm

10 Gazete ve dergi adlarından sonra yer alan parantez içerisindeki bilgiler Milli Kütüphane tarafindan verilen yer numarasını ifade etmektedir. İlgili gazete ve dergilerden Anadolu, Babalık, Ekekon, Folklor Postası, Işık, Öz Demokrat Konya, SSehir Postası'nın tamamı; Konya Halkevi'nin 1942-1950 yılları arasındaki sayıları; Anadolu-Manșet'in 2005 yılına kadar olan sayıları; diğerlerinin ise Aczî’nin vefat yılı olan 1965 yılına kadar olan sayıları taranmıştır. İlgili süreli yayınlar fizikî olarak taranmıştır. 
Hanım'dır (öl. 1910). İbrahim Aczî, Soyadı Kanunu ile "Kendi" soyadını almayı tercih etmiştir. ${ }^{11}$

Eğitimine Konya Ereğli'sinin Divle nahiyesinde başlayan İbrahim Aczî; sırası ile Konya Piri Mehmet Paşa Mektebi, Molla Efendi Medresesi, Konya İdâdî Mektebi ve İstanbul Mülkiye Mektebi'nde eğitim hayatını sürdürmüştür. ${ }^{12}$ II. Abdülhamit yönetimi tarafından sakıncalı olarak görülen Mithat Paşa'nın (öl. 1884) savunma nutkunun odasında bulunması sebebiyle Mithat Paşa'ya ve onun düşüncesine yakın olarak görüldüğü için Mülkiye Mektebinden sürgün edilen Aczî'nin eğitim hayatı sekteye uğramış ve Aczî Konya'ya gönderilmiștir. Dönemin Konya valisi Ferit Paşa tarafından Konya Yol Mühendisliği Evrak Kâtipliğine tayin edilen Aczî,13 devlet kademesinde memurluk, nahiye müdürlüğü, öğretmenlik ve başöğretmenlik yaptıktan sonra 1936 yllında emekliye ayrılmıştır. ${ }^{14}$

Aczî̀nin dil öğrenmeye ve sanata olan ilgisi de dikkat çekmektedir. 0, Arapça ve Farsça eğitimi görmüş; bir müddet Fransız mektebinde Fransızca dersleri dahi almıştır. Dile olan ilgisinin yanında keman, resim ve hat gibi güzel sanatlar alanında da kendisini geliștirmiştir. Resme olan vukûfiyeti yapmıș olduğu eserlerde kendini göstermektedir. ${ }^{15}$

İbrahim Aczî, Şerife Hanım ve Mehmed Emin Efendi'nin kızı Semiye Hanım (öl. 1975) ile 20 Nisan 1320/3 Mayıs 1904 tarihinde evlenmiştir. ${ }^{16}$ Onun bu evlilikten Behiye, Mahmude, Mahmudiye, Mahmut Havfi, Ali Tarık, Kamerşah ve Ahmet Cenap olmak üzere yedi çocuğu olmuştur. ${ }^{17}$

İbrahim Aczî, 6 Ağustos 1965 Cuma günü hastalanmıș18 ve bu hastalığı neticesinde Konya'da bulunan evinde 9 Ağustos 1965 Pazartesi günü ahirete irtihal etmiștir. Aczî, Konya Kapı Camisinde kılınan cenaze namazının akabinde Üçler Mezarlığına defnedilmiștir. ${ }^{19}$

11 İbrahim Aczî Kendi, Dīvān-ı 'Aczī (Konya: Yusuf Ağa Kütüphanesi, 42 Yu 10437), 354b; İbrahim Aczî Kendi, Hayal Bahçesi ve Hayatım (Konya: Yusuf Ağa Kütüphanesi, 42 Yu 11761), 1932, 1. cilt, 57; Kendi, "Babam İbrahim Aczi Kendi", https://www.memleket.com.tr/babam-ibrahim-Aczî-kendi-25755yy.htm; Ceylan, "İbrahim Aczi Kendi (1883-1965)”, 274-275.

12 İbrahim Aczî Kendi, Hayātım ve Hayāl Bāg çesi (Konya: Yusuf Ağa Kütüphanesi, 42 Yu 10451/1), Aladağ, 1327, 1. cilt, 20a; Kendi, Hayal Bahçesi ve Hayatım (42 Yu 11761), 1. cilt, 24, 34, 81-82, 156-158; Kendi, Dìvān-ı 'Aczì (42 Yu 10437), 4a.

13 Kendi, Hayal Bahçesi ve Hayatım (42 Yu 11761), 1. cilt, 160-161, 180; Kendi, Dīvān-ı 'Aczì (42 Yu 10437), 355a.

14 Aczî’nin yapmış olduğu görevler şunlardır: Konya Nâfia Kalemi Evrak Kâtipliği, Konya Yol Mühendisliği Evrak Kâtipliği, Hatunsaray Tahrîrât Kâtipliği, Karaman Maliye Kâtipliği, Karaman Nüfus Memurluğu, Aladağ Nahiye Müdürlüğü, Barla Nahiye Müdürlüğü, Af̧̧ar Nahiye Müdürlüğü, Hatunsaray Öğretmenliği, Akviran Başöğretmenliği, Hadim Öğretmenliği, Balkar Öğretmenliği, Gözlü Öğretmenliği.

15 Kendi, Hayal Bahçesi ve Hayatım (42 Yu 11761), 1. cilt, 63-64, 290; Kendi, Hayātım ve Hayāl Bāg̣çesi (42 Yu 10451/1), 1. cilt, 137a-137b; Kendi, Dīvān-ı 'Aczī (42 Yu 10437), 4a; Uyar, "Hattatlar Armağanı", 11.

16 Ceylan, "İbrahim Aczi Kendi (1883-1965)", 274-275.

17 Kendi, Hayātım ve Hayāl Bāg̣çesi ( 42 Yu 10451/1), 1. cilt, 120a; Kendi, Hayal Bahçesi ve Hayatım (42 Yu 11761), 1. cilt, 261; İbrahim Aczî Kendi, Hayal Bahçesi ve Hayatım (Konya: Yusuf Ağa Kütüphanesi, $42 \mathrm{Yu}$ 11765), 1932, 2. cilt, 87-88; Ceylan, “İbrahim Aczi Kendi (1883-1965)”, 274-275.

18 İbrahim Aczî Kendi, “Avcılık Âlemi”, Yeni Meram (14 Ağustos 1965), 3. (Gazete yönetiminin ilgili tefrikada yapmış olduğu bilgilendirme yazısından alınmıştır.)

19 Kendi, "Babam İbrahim Aczi Kendi", https://www.memleket.com.tr/babam-ibrahim-Aczî-kendi25755yy.htm (09/04/2020); Ceylan, “İbrahim Aczi Kendi (1883-1965)”, 277; Uz, Konya Kültürüne Hizmet Edenler, 44; Ahmet Çelik, Osmanlı'dan Cumhuriyet'e Konya Öğretmenleri (Konya: Konya Belediyesi Kültür Yayınları 414, 2020), 121.

https://dergipark.org.tr/tr/pub/atebe 


\section{1.İbrahim Aczî'ye Ait Olan Eserler}

\subsection{Yazma Eserleri}

Kendi, İbrahim Aczî. 'Āşı ḳ Dertli Konya'da. Konya: Karatay Yusuf Ağa Kütüphanesi, 42 Yu 10467, 1a-95a.

Kendi, İbrahim Aczî. 'Āşlḳlar-Dîvân Şācirleri. Konya: Karatay Yusuf Ağa Kütüphanesi, 42 Yu 10471, 1a-154b.

Kendi, İbrahim Aczî. Āyāşlı Şākir. Konya: Karatay Yusuf Ağa Kütüphanesi, 42 Yu 10464, 1a-32a.

Kendi, İbrahim Aczî. Bilgi Anahttarı. Konya: Karatay Yusuf Ağa Kütüphanesi, 42 Yu 10473, 1a-197b.

Kendi, İbrahim Aczî. Cönkler ve 'Āşıklar. Konya: Karatay Yusuf Ağa Kütüphanesi, Demirbaş no 10474, 1a-178a.

Kendi, İbrahim Aczî. Devirler Arası Konya. Konya: Karatay Yusuf Ağa Kütüphanesi, $42 \mathrm{Yu} 10475,1 \mathrm{a}-23 \mathrm{~b}$.

Kendi, İbrahim Aczî. Devr-i Zamān Rubāịlerim. 2 cilt, Konya: Karatay Yusuf Ağa Kütüphanesi, 42 Yu 10465.

Kendi, İbrahim Aczî. Dīvān-ı 'Aczī. Konya: Karatay Yusuf Ağa Kütüphanesi, 42 Yu 10437, 1a-356b.

Kendi, İbrahim Aczî. Dünyā Ufuklarında. Konya: Karatay Yusuf Ağa Kütüphanesi, 42 Yu 10452, 1a-42a.

Kendi, İbrahim Aczî. Dünyāya Bakarak. Konya: Karatay Yusuf Ağa Kütüphanesi, 42 Yu 10463, 1a-13a.

Kendi, İbrahim Aczî. Ebü'l- 'Alā. Konya: Karatay Yusuf Ağa Kütüphanesi, 42 Yu 10462, 1a-47b.

Kendi, İbrahim Aczî. Fażāilü'd-Dīn. Konya: Karatay Yusuf Ağa Kütüphanesi, 42 Yu 10458, 1a-82b.

Kendi, İbrahim Aczî. Felek Rūzgārı. Konya: Karatay Yusuf Ağa Kütüphanesi, 42 Yu 10484, 1a-56b.

Kendi, İbrahim Aczî. Güldeste Mi Isırǵan Otu Mu. Konya: Karatay Yusuf Ağa Kütüphanesi, 42 Yu 10479, 1a-19b.

Kendi, İbrahim Aczî. Havās Hazīnesi. Konya: Karatay Yusuf Ağa Kütüphanesi, 42 Yu 10477, 1a-35b.

Kendi, İbrahim Aczî. Hayāl Bäğçesi Rubāîler. Konya: Karatay Yusuf Ağa Kütüphanesi, 42 Yu 10451, 1a-29a. ${ }^{20}$

Kendi, İbrahim Aczî. Hayātım ve Hayāl Bāğçesi. 3 cilt, Konya Karatay Yusuf Ağa Kütüphanesi, 42 Yu 10451.

20 Bu eser, Hayātım ve Hayāl Bā gçesi (42 Yu 10451) adlı eserin 3. cildinin sonuna eklenmiştir. Eser cep boy şeklinde olup ayrı olarak ciltlidir. Yusuf Ağa Kütüphanesi tarafindan esere katalog numarası verilmediğinden tarafimızca Hayātım ve Hayāl Bāgsçesi (42 Yu 10451) eserinin katalog numaras1 verilmiştir. 
İbrahim Aczî Kendi Bibliyografyası

Kendi, İbrahim Aczî. Hazīne-i Eşāar. Konya: Karatay Yusuf Ağa Kütüphanesi, 42 Yu 10461, 1a-227a.

Kendi, İbrahim Aczî. Ḥikāyelerim. Konya: Karatay Yusuf Ağa Kütüphanesi, 42 Yu 10468, 1a-17a.

Kendi, İbrahim Aczî. Hikâyelerim Olag̉an Şeyler. Konya: Karatay Yusuf Ağa Kütüphanesi, 42 Yu 10469, aa-40b.

Kendi, İbrahim Aczî. İlāhī Tecellī, Dünyā, İnsānlar ve Velīler. Konya: Karatay Yusuf Ağa Kütüphanesi, 42 Yu 10455.

Kendi, İbrahim Aczî. 'İlim ve ‘Ālim. Konya: Karatay Yusuf Ağa Kütüphanesi, 42 Yu 10478, 1a-44a.

Kendi, İbrahim Aczî. Kendimizi Tanıyalım. Konya: Karatay Yusuf Ağa Kütüphanesi, $42 \mathrm{Yu} 10483,1 \mathrm{a}-13 \mathrm{a}$.

Kendi, İbrahim Aczî. Konya Mezār Folḳloru. Konya: Karatay Yusuf Ağa Kütüphanesi, $42 \mathrm{Yu}$ 10457, 1a-55a.

Kendi, İbrahim Aczî. Mevlānā ve 'Āriflerin Dili. Konya: Karatay Yusuf Ağa Kütüphanesi, 42 Yu 10450, 1a-64a.

Kendi, İbrahim Aczî. Mevlānā 'Asş̣ ve Rubā'īleri. Konya: Karatay Yusuf Ağa Kütüphanesi, 42 Yu 10441, 1a-65b.

Kendi, İbrahim Aczî. Mevlānā ve Cihān. Konya: Karatay Yusuf Ağa Kütüphanesi, 42 Yu 10446, 1a-325b.

Kendi, İbrahim Aczî. Mevlānā ve Cihān. Konya: Karatay Yusuf Ağa Kütüphanesi, 42 Yu 10447, 1a-389b.

Kendi, İbrahim Aczî. Mevlānā ve Rūh-ı Meșnevī. Konya: Karatay Yusuf Ağa Kütüphanesi, 42 Yu 10436, 1a-168b.

Kendi, İbrahim Aczî. Mevlānā ve Vaḥdet Sirrı. Konya: Karatay Yusuf Ağa Kütüphanesi, 42 Yu 10449, 1a-141a.

Kendi, İbrahim Aczî. Muhịț ve Çocuḳlar. Konya: Karatay Yusuf Ağa Kütüphanesi, 42 Yu 10480, 1a-65b.

Kendi, İbrahim Aczî. ‘Ömer Hayyām. Konya: Karatay Yusuf Ağa Kütüphanesi, 42 Yu 10466, 1a-55b.

Kendi, İbrahim Aczî. Pāşālar ve Cellādlar. Konya: Karatay Yusuf Ağa Kütüphanesi, $42 \mathrm{Yu} 10482,1 \mathrm{a}-32 \mathrm{a}$.

Kendi, İbrahim Aczî. Ravżatü'l-'Ușşāk. Konya: Karatay Yusuf Ağa Kütüphanesi, 42 Yu 10481, 1a-184b.

Kendi, İbrahim Aczî. Şehādet-i Hażret-i Ḥüseyin. Konya: Karatay Yusuf Ağa Kütüphanesi, 42 Yu 10453, 1a-25a.

Kendi, İbrahim Aczî. TTıbbî Notlar ve Edebī Derlemeler. Konya: Karatay Yusuf Ağa Kütüphanesi, 42 Yu 10443, 1a-40b.

Kendi, İbrahim Aczî. Türk Şāiir ve 'Asşıkları. 3 cilt, Konya: Karatay Yusuf Ağa Kütüphanesi, 42 Yu 10470. 

$1 \mathrm{a}-39 \mathrm{~b}$

Kendi, İbrahim Aczî. Yādigār. Konya: Karatay Yusuf Ağa Kütüphanesi, 42 Yu 10456, 11783.

Kendi, İbrahim Aczî. Resim Albümü. Konya: Karatay Yusuf Ağa Kütüphanesi, 42 Yu

\subsection{Latin Harfli Eserleri}

Kendi, İbrahim Aczî. Hayal Bahçesi ve Hayatım. 1. Cilt. Konya: Karatay Yusuf Ağa Kütüphanesi, 42 Yu 11761.

Kendi, İbrahim Aczî. Hayal Bahçesi ve Hayatım. 2. Cilt. Konya: Karatay Yusuf Ağa Kütüphanesi, 42 Yu 11765.

Kendi, İbrahim Aczî. Hayal Bahçesi ve Hayatım. 3. Cilt. Konya: Karatay Yusuf Ağa Kütüphanesi, 42 Yu 11764.

Kendi, İbrahim Aczî. Hayal Bahçesi ve Hayatım. 4. Cilt. Konya: Karatay Yusuf Ağa Kütüphanesi, 42 Yu 11763.

Kendi, İbrahim Aczî. Hayal Bahçesi Rubâîler. Konya: Karatay Yusuf Ağa Kütüphanesi, 42 Yu 11762.

Kendi, İbrahim Aczî. Antoloji Âşıklar Şâirler Konuşuyor (Dîvân Şâirleri), Konya: Karatay Yusuf Ağa Kütüphanesi, 42 Yu 11779.

\subsection{Matbu Eserleri}

Kendi, İbrahim Aczî. Âşılk Şem'î Konuşuyor. Konya: Yeni Kitap Basımevi, 1951.

Kendi, İbrahim Aczî. Felek Rüzgarı. Konya: Yıldız Basımevi, 1961. 1954.

Kendi, İbrahim Aczî. Hayal Bahçesi ve Hayatî Kıt'alarım. Konya: Güven Matbaası,

Kendi, İbrahim Aczî. Mevlâna ve Ruh-u Mesnevi 1 inci Kitap. Konya: Yeni Kitap Basımevi, 1953.

Kendi, İbrahim Aczî. Mevlânâ ve Ruhu Mesnevî. Konya: Kanaat Matbaası, 1959.

\subsection{Gazete Yazıları}

\subsubsection{Anadolu Gazetesi}

Kendi, İbrahim Aczî. “Ramazan Sohbetleri”. Anadolu (17 Ocak 1964-14 Şubat 1964).

Kendi, İbrahim Aczî. "Deryadiliz”. Anadolu (27 Şubat 1964), 2.

Kendi, İbrahim Aczî. "Kendimizi Tanıyalım". Anadolu (23 Mart 1964-4 Haziran 1964)/ 28 Tefrika.

Kendi, İbrahim Aczî. "Sevakıbı Mevlânâ". Anadolu (20 Haziran 1964-19 Eylül 1964)/ 62 Tefrika. Tefrika.

Kendi, İbrahim Aczî. "Gazete”, Anadolu (11 Kasım 1964-22 Aralık 1964)/ 27

Kendi, İbrahim Aczî. “Şiir Demeti Semai”. Anadolu (29 Aralık 1964), 3.

\subsubsection{Işık}


İbrahim Aczî Kendi Bibliyografyası

Kendi, İbrahim Aczî. “İnsan Oğulları Mevlânâ ve Âriflerin Dili”. Işık (21 Mayıs 196211 Temmuz 1962)/ 45 Tefrika. Tefrika.

Kendi, İbrahim Aczî. “Âlem ve Ahlak”. Işılk (20 Temmuz 1962-28 Ağustos 1962) /34

Kendi, İbrahim Aczî. “Devirler Arası Konya”. Işılk (25 Eylül 1962-10 Aralık 1962)/ 56 Tefrika.

Kendi, İbrahim Aczî. “Mevlânâ ve Son Gece”. Işılk (17 Aralık 1962), 2. Tefrika.

Kendi, İbrahim Aczî. "Âşıklar ve Güzeller". Işılk (3 Ocak 1963-9 Nisan 1963)/ 82

Kendi, İbrahim Aczî. “Şiir Demeti Şu Dağlar”. Işsık (16 Nisan 1963), 3.

Kendi, İbrahim Aczî. “Şiir Demeti Dağ Güzeli”. Işsı (17 Nisan 1963), 3.

Kendi, İbrahim Aczî. "Şiir Demeti İlkbahar”. Işılk (18 Nisan 1963), 3.

Kendi, İbrahim Aczî. "Şiir Demeti İlkbahar ve Bülbül”. Işsk (19 Nisan 1963), 3.

Kendi, İbrahim Aczî. "Şiir Demeti Geçmiş Hatıralar”. Işsı (23 Nisan 1963), 3.

Kendi, İbrahim Aczî. “Şiir Demeti Geçmiş Hatıralar Altın Oluk”. Işılk (26 Nisan 1963), 3.

Kendi, İbrahim Aczî. "Şiir Demeti İhtiras Bir Tayfon”. Işık (1 Mayıs 1963), 3.

Kendi, İbrahim Aczî. "Şiir Demeti Şafak ve Dağlar”. Işılk (3 Mayıs 1963), 3.

Kendi, İbrahim Aczî. "Şiir Demeti İhtiras ve Muhteris". Işsı (8 Mayıs 1963), 3.

Kendi, İbrahim Aczî. “Şiir Demeti Ey Vatanım”. Işıı (9 Mayıs 1963), 3.

Kendi, İbrahim Aczî. "Atasözlerinin Mana ve Hikmetleri”. Işılk (7 Ağustos 1963-7 Eylül 1963)/ 27 Tefrika. Tefrika.

Kendi, İbrahim Aczî. “Leyla ve Mecnun”, Işsk (27 Kasım 1963-19 Şubat 1964)/ 51

Kendi, İbrahim Aczî. "Mevlânâ ve Aşk", Işılk (17 Aralık 1963), 3.

Kendi, İbrahim Aczî. "Konya Daha Temiz ve Medeni Bir Şehir Olabilir Mi?", Işık (14/15 Mayis 1964).

Kendi, İbrahim Aczî. “İki Parça”, Işılk (8 Haziran 1964), 3.

Kendi, İbrahim Aczî. "Bilgin Nasıl Olunur”, Işık (3 Temmuz 1964), 2.

Kendi, İbrahim Aczî. “Osmanlı Sarayında Paşalar-Cellatlar”, Işılk ( 27 Temmuz 196426 Ağustos 1964)/ 14 Tefrika.

Kendi, İbrahim Aczî. "Bir Geziden Notlar: İstanbul Topkapı Önünde 12 Temmuz 1964", Işık (22/25/28 Eylül 1964-1/5/8/12/15 Ekim 1964).

Kendi, İbrahim Aczî. "Hazreti Mevlânâ Deveran ve Huzur", Işık (4 Ocak 1956-25 Ocak 1965).

\subsection{3.Öz Demokrat Konya Gazetesi}

Kendi, İbrahim Aczî. “Tatlı Tenkid”. Öz Demokrat Konya (29-31 Ocak 1958). 
Kendi, İbrahim Aczî. "Sayın Aynur'a”. Öz Demokrat Konya (6 Şubat 1958), 2.

Kendi, İbrahim Aczî. "60 Yıl Önce Konya Folklor Âlemi”. Öz Demokrat Konya (1 Mart-14 Mayis 1958).

Kendi, İbrahim Aczî. "Devran Köşesi: Gün Așırı”. Öz Demokrat Konya (21/23/25 Mayıs 1958). 2.

Kendi, İbrahim Aczî. “Devran Köşesi: Felsefe”. Öz Demokrat Konya (26 Mayıs 1958),

Kendi, İbrahim Aczî. “Devran Köșesi: Devran ve Âşılar”. Öz Demokrat Konya (27 Mayıs- 1 Haziran 1958).

Kendi, İbrahim Aczî. "Avcılık ve Ruhi Spor-Av Âleminin Ruhi ve Hayati Meraklı Safhaları". Öz Demokrat Konya (16-27 Haziran 1958)/ 9 Tefrika.

Kendi, İbrahim Aczî. “Düşünceler: Hakikat Hakkın Yolu, Ondan Bahsedenler Hakkın Has Kuludur". Öz Demokrat Konya (8 Temmuz 1958), 2.

Kendi, İbrahim Aczî. “Kıbrıs: Hak Ölmedi, Ölmez ve Ölmeyecek”. Öz Demokrat Konya (11 Temmuz 1958), 2.

Kendi, İbrahim Aczî. “Olağan Şeyler”. Öz Demokrat Konya (22 Temmuz 1958), 3.

Kendi, İbrahim Aczî. "Felsefe ve Dünya”. Öz Demokrat Konya (11-17 Ağustos 1958).

2.

Kendi, İbrahim Aczî. “ Gönül Hakikat Evi”. Öz Demokrat Konya (28 Ağustos 1958),

Kendi, İbrahim Aczî. “Asırların Unutturamadığı Hikayeler”. Öz Demokrat Konya (24 Kasım-5 Aralık 1958).

Kendi, İbrahim Aczî. " Eleștirme: Mevlânâ ve Mesnevî". Öz Demokrat Konya (29 Aralık 1958), 3.

Kendi, İbrahim Aczî. "Eleştirme: Güdümlü Mermi”. Öz Demokrat Konya (30 Aralık 1958), 3.

Kendi, İbrahim Aczî. “ Mevlânâ Destânı”. Öz Demokrat Konya (24 Ocak 1959), 2.

Kendi, İbrahim Aczî. "Gönüller Sultanı Mevlânâ”. Öz Demokrat Konya (15 Nisan 1959), 2.

Kendi, İbrahim Aczî. " Ata Sözleri”. Öz Demokrat Konya (4 Haziran-24 Temmuz 1959)/ 14 Tefrika.

Kendi, İbrahim Aczî. “ Bir Telif Babında ve İlim Yayma Derneği”. Öz Demokrat Konya (16 Ekim 1959), 2.

Kendi, İbrahim Aczî. “ Hey Gidi Günler Hey: Bir Garip Hikaye”. Öz Demokrat Konya (24 Haziran 1960), 2.

\subsubsection{Sabah Gazetesi}

Kendi, İbrahim Aczî. “Her Gün Bir Şiir”. Sabah (14-16 Haziran 1961). 42 Tefrika.

Kendi, İbrahim Aczî. “Felek Rüzgarı”. Sabah (17 Haziran 1961-21 Ağustos 1961)/ 
İbrahim Aczî Kendi Bibliyografyası

Kendi, İbrahim Aczî. “Toros Dağlarında”. Sabah (22 Mayıs 1962-31 Ekim 1962)/ 108 Tefrika.

Kendi, İbrahim Aczî. “Olur Mu”. Sabah (2 Temmuz 1962), 2.

Kendi, İbrahim Aczî. "Kendi Köșesinden”. Sabah (3/5/7/8/9/10 Kasım 1962).

Kendi, İbrahim Aczî. “Dünya Ufuklarında”. Sabah (21 Kasım 1962-25 Ocak 1963)/ 43 Tefrika.

Kendi, İbrahim Aczî. "Eski Devirler ve Ramazan". Sabah (1 Şubat 1963-21 Şubat 1963)/ 16 Tefrika.

Kendi, İbrahim Aczî. “Toros Dağlarında (İkinci Kısım)”. Sabah (13 Mart 1963-4 Haziran 1963).

Kendi, İbrahim Aczî. "Kendi Kendime Son Tavsiye”. Sabah (26-27 Nisan 1963).

Kendi, İbrahim Aczî. "Hafız Şirazi Konuşuyor”. Sabah (8 Ağustos 1963-28 Ağustos 1963)/ 15 Tefrika. Tefrika.

Kendi, İbrahim Aczî. “Aşk ve Âșılklar”. Sabah (27 Kasım 1963-31 Aralık 1963)/ 28 1964).

Kendi, İbrahim Aczî. "Hikmet Dâhisi Ömer Hayyam”. Sabah (5 Mart 1964-16 Nisan

\subsubsection{Yeni Konya}

Kendi, İbrahim Aczî. “Âşılk Şem’i Konuşuyor”. Yeni Konya (19 Şubat 1951-13 Ekim 1951)/ 113 Tefrika.

Kendi, İbrahim Aczî. “60 Yıl Önce Konya (Eski Eserler-Türbeler-Çeşmeler-Mezarlar ve Kitabeler)". Yeni Konya (23 Kasım 1951-28 Kasım 1951)/ 4 Tefrika.

Kendi, İbrahim Aczî. "Konya Halk Şairleri”. Yeni Konya (23 Aralık 1951-30 Aralık 1951)/ 6 Tefrika.

Kendi, İbrahim Aczî. “Tahvil: Nazireye, nazire...!”. Yeni Konya (18 Şubat 1952), 3.

Kendi, İbrahim Aczî. "Birbirini Nakseden Teskere ve Sicil İsimleri Saymak İlim Değildir". Yeni Konya (25/26/27/28 Şubat 1952-3/4/5 Mart 1952)

Kendi, İbrahim Aczî. “Âșık Șem'i için, Cahit Öztelli İmzasıyla Yazılan Tenkide Cevap”. Yeni Konya (15 Mayıs 1952), 2.

Kendi, İbrahim Aczî. "Geciken Cevaba Son Cevabımız Sayın Cahit Öztelliye”. Yeni Konya (23-25 Ekim 1952).

Kendi, İbrahim Aczî. “Mevlana'yı Anma Gecesinden Konya'da Lâhûtî Bir Gece”. Yeni Konya (21 Aralık 1952-14 Ocak 1953)/ 13 Tefrika.

Kendi, İbrahim Aczî. “Dünya ve İnsanlar”. Yeni Konya (13 Şubat 1953-2 Mart 1953)/ 13 Tefrika.

Kendi, İbrahim Aczî. "Güzeller, Cazibesi ve Âşıklar". Yeni Konya (4 Nisan 1953-22 Nisan 1953)/ 11 Tefrika.

Kendi, İbrahim Aczî. "Devran Köşesi". Yeni Konya Gazetesi, 5/10/18/24 Ocak1/3/5/11 Şubat-3/5 Nisan 1954 (10 Şiir). 
Kendi, İbrahim Aczî. "Yeni Bir Rivayet Yazısı". Yeni Konya (2 Ocak 1955), 2.

Kendi, İbrahim Aczî. "Dergiler". Yeni Konya (28 Ocak 1955), 2.

Kendi, İbrahim Aczî. “Gök Dede”. Yeni Konya (5 Şubat 1955), 2.

Kendi, İbrahim Aczî. "Peynir Gemisi”. Yeni Konya (27 Temmuz 1955), 3.

Kendi, İbrahim Aczî. “Mevlana ve Divan-ı Kebir”. Yeni Konya (6 Ocak 1956), 2.

Kendi, İbrahim Aczî. "Türk Mızrabı Güzellik-Güzeller ve Âşıklar”. Yeni Konya (10 Ocak 1956-21 Şubat 1956)/ 17 Tefrika.

Kendi, İbrahim Aczî. "Mevlana Diyor Ki”. Yeni Konya (12 Ocak 1956), 2.

Kendi, İbrahim Aczî. "Aczi'nin Gülü Cevab-ı Dandin Şikâf". Yeni Konya (28 Ocak 1956), 2.

Kendi, İbrahim Aczî. "Hakikat Karşısında”. Yeni Konya (5 Mayıs 1956), 2.

Kendi, İbrahim Aczî. "Hak-Hakikat”. Yeni Konya (8 Mayıs 1956), 2.

Kendi, İbrahim Aczî. "Dârâ ve İskender". Yeni Konya (29 Ağustos 1956-18 Eylül 1956)/ 12 Tefrika.

Kendi, İbrahim Aczî. "Cengiz ve Harzimşah". Yeni Konya (22 Ocak 1957-1 Mart 1957)/ 30 Tefrika.

Kendi, İbrahim Aczî. "Konya Folkloru Âşıklar Dilinden". Yeni Konya (17 Temmuz 1958-2 Eylül 1958).

Kendi, İbrahim Aczî. “Tenkit Nedir”. Yeni Konya (13 Eylül 1958-2 Aralık 1958)/ 32 Tefrika.

Kendi, İbrahim Aczî. “Mersiye”. Yeni Konya (7 Aralı 1958), 2.

Kendi, İbrahim Aczî. “Mevlana İhtifalinin Sonunda”. Yeni Konya (31 Aralık 1958/7 Ocak 1959).

Kendi, İbrahim Aczî. “Konya Mezar Folkloru”. Yeni Konya (3 Ağustos 1959-9 Kasım 1959)/ 41 Tefrika.

Kendi, İbrahim Aczî. “Hazire Kelimesi Üzerine”. Yeni Konya (3 Kasım 1959), 2. 1959), 2.

Kendi, İbrahim Aczî. "Külliyatı Letâif Fıkrasına Evet Öyle". Yeni Konya (13 Kasım

Kendi, İbrahim Aczî. "Kâinat ve Dağlarla Hasbihal". Yeni Konya (9 Ocak 1960-20 Ocak 1960)/ 8 Tefrika.

Kendi, İbrahim Aczî. "Değişmiş”. Yeni Konya (17 Şubat 1960), 2.

Kendi, İbrahim Aczî. "Âşık Dertli Konya'da”. Yeni Konya (20 Şubat 1960-6 Nisan 1960)/ 13 Tefrika.

Kendi, İbrahim Aczî. “İlimde Sinsi Rekabet Var Mı?”. Yeni Konya (26 Nisan 1961-4 Mayıs 1961)/ 6 Tefrika.

Kendi, İbrahim Aczî. "Dağlar Tabiat, Büyük Küçük Hayvanlar ve Kuşlar”. Yeni Konya (9 Ağustos 1975), 2-3. 
İbrahim Aczî Kendi Bibliyografyası

\subsubsection{Yeni Meram}

Kendi, İbrahim Aczî. "Așk ve Mevlânâ Celaleddini Rumi”. Yeni Meram (2 Haziran 1951-6 Eylül 1951)/ 65 Tefrika.

Kendi, İbrahim Aczî. “İhtifal Destanı”. Yeni Meram (21 Aralık 1954), 2.

Kendi, İbrahim Aczî. “Tetkikler: Âşık Şemi İçin”. Yeni Meram (10 Mart 1955), 2.

Kendi, İbrahim Aczî. “Terbiye: Hırs ve Muhtekir”. Yeni Meram (22 Mart 1955), 2.

Kendi, İbrahim Aczî. “Terbiye: Müdahin”. Yeni Meram (23 Mart 1955), 2.

Kendi, İbrahim Aczî. “Terbiye Bahsi: Taassup”. Yeni Meram (24 Mart 1955), 2.

Kendi, İbrahim Aczî. “Hak Âşıkları ve Taassup”. Yeni Meram (30/31 Mart 1955).

Kendi, İbrahim Aczî. "Manevi Hikayeler”. Yeni Meram (3 Nisan 1955), 3.

Kendi, İbrahim Aczî. "Manevi Hikayeler Vurguncu Sinek". Yeni Meram (6 Nisan 1955), 2.

Kendi, İbrahim Aczî. "Mevlânâ ve Sema”. Yeni Meram (8 Nisan 1955), 2.

Kendi, İbrahim Aczî. “Türk Saz ve Mızrabı”. Yeni Meram (12 Nisan 1955), 2.

Kendi, İbrahim Aczî. “Türk Mızrabı”. Yeni Meram (24 Nisan 1955-12 Mayıs 1955).

Kendi, İbrahim Aczî. "Yeni Neşir: Konya Çeşme ve Şadırvanları İsimli Eser Üzerine”. Yeni Meram (5 Ağustos 1955), 2.

Kendi, İbrahim Aczî. "Dünyaya”. Yeni Meram (16 Ocak 1957), 3. 30 Tefrika.

Kendi, İbrahim Aczî. “Dünya Güzelleri”. Yeni Meram (19 Ocak 1957-21 Şubat 1957)/

Kendi, İbrahim Aczî. "Ayaşlı Şakir Bey Hayatı ve Eserleri”. Yeni Meram (8 Mart 1957-23 Nisan 1957).

Kendi, İbrahim Aczî. “Huy Semaisi”. Yeni Meram (7 Temmuz 1957), 2.

Kendi, İbrahim Aczî. “Köşeden Hayat Semaisi”. Yeni Meram (14 Temmuz 1957), 2.

Kendi, İbrahim Aczî. “Devran ve Âşıklar”. Yeni Meram (13 Kasım 1957), 3.

Kendi, İbrahim Aczî. “Mevlânâ ve Gülșen-i Tevhid”. Yeni Meram (21 Ağustos 1959), 2

Kendi, İbrahim Aczî. "Avcllı Âlemi”. Yeni Meram (9 Temmuz 1965-14 Ağustos 1965)/ 30 Tefrika.

\subsection{Dergi Yazıları} 48-55.

Kendi, İbrahim Aczî. “Âşıklar”. Konya Halkevi Aylık Kültür Dergisi/42 (Nisan 1942),

Kendi, İbrahim Aczî. “Âşılk Derviş̧̂”. Konya Halkevi Aylık Kültür Dergisi/43 (Mayıs 1942), 40-44.

Kendi, İbrahim Aczî. "Âşılk Kul Mustafa”. Konya Halkevi Aylık Kültür Dergisi/44 (Haziran 1942), 49-53.

https://dergipark.org.tr/tr/pub/atebe 
Kendi, İbrahim Aczî. "Âşık Kul Mahmut”. Konya Halkevi Aylık Kültür Dergisi/45 (Temmuz 1942), 47-50.

Kendi, İbrahim Aczî. "Karacaoğlan”. Konya Halkevi Aylık Kültür Dergisi/46 (Ağustos 1942), 46-65.

Kendi, İbrahim Aczî. "Âşık İrgin". Konya Halkevi Aylık Kültür Dergisi/48 (Birinci Teşrin 1942), 55-59.

Kendi, İbrahim Aczî. "Âşık Muslu". Konya Halkevi Aylık Kültür Dergisi/49 (İkinci Teşrin 1942), 55-61.

Kendi, İbrahim Aczî. "Âşık Hüseyin". Konya Halkevi Aylık Kültür Dergisi/50 (Birinci Kanun 1943), 43-50.

Kendi, İbrahim Aczî. "Âşık Çaloğlu". Konya Halkevi Aylık Kültür Dergisi/51 (İkinci Kanun 1943), 42-46.

Kendi, İbrahim Aczî. "Âşık Abdal Hasan". Konya Halkevi Aylık Kültür Dergisi/52 (Şubat 1943), 17-28.

Kendi, İbrahim Aczî. "Âşılk Hicrânî". Konya Halkevi Aylık Kültür Dergisi/58-59 (Ağustos-Eylül 1943), 44-48.

Kendi, İbrahim Aczî. "Cönkler, Şairler, Âşılklar". Konya Halkevi Ayllk Kültür Dergisi/97-98 (Kasım-Aralık 1964), 9-11.

Kendi, İbrahim Aczî. "Cönkler Âşıklar Âşık Sazlı". Konya Halkevi Aylık Kültür Dergisi/102-104 (Nisan-Mayıs-Haziran 1947), 8-9.

Kendi, İbrahim Aczî. "Şairler, Âşıklar". Konya Halkevi Aylık Kültür Dergisi/108-110 (Ekim-Kasım-Aralık 1947), 10-12.

Kendi, İbrahim Aczî. "Mitholoji Âşıklar-Cönkler Halk Şairi Sadâ̂”. Konya Halkevi Ayllk Kültür Dergisi/118-119 (Ağustos-Eylül 1948), 18-20.

Kendi, İbrahim Aczî. "Şairler Âșıklar Şair Fahrî". Konya Halkevi Aylık Kültür Dergisi/120-121 (Ekim-Kasım 1948), 37-40.

Kendi, İbrahim Aczî. “Âşılk Hikmetî”. Folklor Postası 1/7 (Nisan 1945), 12.

\section{Tercüme ya da İstinsah Ettiği Eserler}

Âşık Şem'i. Dîvân-ı Şem'î Baba. İstinsah eden İbrahim Aczî Kendi. Konya: Karatay Yusuf Ağa Kütüphanesi, 42 Yu 10472, 1a-95b.

Fuzûlî. Rind u Zâhid. Tercüme İbrahim Aczî Kendi. Konya: Karatay Yusuf Ağa Kütüphanesi, 42 Yu 10460, 1a-47b.

Melekzâde Rüstem Dârâ. Şâhnâme-i Âhi. İstinsah eden İbrahim Aczî Kendi. Konya: Karatay Yusuf Ağa Kütüphanesi, 42 Yu 10459,1a-63b.

Mesnevîhân Mahmud Dede. Sevâkı Tercümesi, İstinsah eden İbrahim Aczî Kendi. Konya: Karatay Yusuf Ağa Kütüphanesi, 42 Yu 10445,1a-147b.

Suyûtî. Kitābu'r-Raḥme fi't-Tıbb ve'l-Hikme. Tercüme İbrahim Aczî Kendi. Konya: Karatay Yusuf Ağa Kütüphanesi, 42 Yu 10439. 
İbrahim Aczî Kendi Bibliyografyası

\section{Hayatı ve Eserleri İle İlgili Yapılan Çalışmalar}

\subsection{Gazete ve Dergilerde Yayınlanan Yazılar}

Ceylan, Serdar. "İbrahim Aczi Kendi (1883-1965)". Merhaba Gazetesi Akademik Sayfalar Vefatının 50. Yılında İbrahim Aczi Kendi (1883-1965) Özel Sayı 15/18 (Haziran 2015), 274-277.

Çelik, Ahmet. "Konya'da Okul Anıları-I İbrahim Aczi'nin Okul Anıları". Merhaba Gazetesi Akademik Sayfalar Vefatının 50. Yılında İbrahim Aczi Kendi (1883-1965) Özel Sayı 15/18 (Haziran 2015), 277-288.

Dikilitaş, Yalçın. "İbrahim Aczi Kendi”. Anadolu Manşet Gazetesi Kültür\&Sanat (5 Ağustos 2004), 2.

Elgin, Necati. "Şair Rasih Hakkında”. Yeni Meram (6 Şubat 1952), 3.

Gölpınarlı, Abdülbâki. “Gül Deste'nin Dikeni Cevâb-ı Dendon-Şiken”. Yeni Konya (26 Ocak 1956), 2.

Halıcı, Feyzi. “Üstat İbrahim Aczi Kendi'nin Ardından”. Sabah (11 Ağustos 1965), 2.

Kendi, Ahmet Cenap. "Ölümünün 10. cu Yılında Şair İbrahim Aczi Kendi”. Yeni Konya (9 Ağustos 1975), 2.

Kendi, Ahmet Cenap. “Ölümünün 15. Yılında İbrahim Aczi Kendi Şair ve Edip, Hayatı ve Eserleri”. Yeni Konya (5 Haziran 1979), 2.

Küçükbezirci, Seyit. “Unutulmayacak Konyalılar Konya'nın Basın, Sanat, Kültür Adamları". Yeni Meram (8 Mart 1982-16 Mart 1982)/ 8 Tefrika.

Öz Demokrat Konya. “Folklorcularımız İbrahim Aczi Kendi” (14 Mayıs 1958), 2.

Öztelli, Cahit. "Folklorcularımız: İbrahim Aczi Kendi”. Türk Folklor Araştırmaları Dergisi 5/104 (Mart 1958), 1658-1659.

Öztelli, Cahit. “Geciken Cevap”. Yeni Konya (16 Ekim 1952), 2.

Öztelli, Cahit. "Konyalıları İlgilendiren Bir Kitap Âşılk Şem'i Konuşuyor”. Yeni Konya (29 Nisan 1952), 2.

3.

Şarkman, Aynur. "Tatlı Tenkide Tatlı Cevap". Öz Demokrat Konya (31 Şubat 1958),

Uyar, Veli Sabri. "Hattatlar Armağanı". Konya Halkevi Aylık Kültür Dergisi/123-124 (Ocak-Şubat 1949), 27-33.

UZLUK, Feridun Nâfiz. "Edebiyat Gerçeğe Uymıanları Sıralamak Değildir". Yeni Konya (5-7 Şubat 1952).

\subsection{Diğer Çalışmalar}

Acar, Ayşe. İbrahim Aczî Kendî̀nin Rubâîleri (Son 180 Rubâî). Konya: Selçuk Üniversitesi, Sosyal Bilimler Enstitüsü, Yüksek Lisans Tezi, 2019.

Aksoyak, İsmail Hakkı. "Taşrada Değerli Bir Kültür Adamı: İbrahim Aczî Kendi”. Prof. Dr. Mehmet Arslan'a Armağan. Editör H. İbrahim Delice vd. 199-204. Sivas: Cumhuriyet Üniversitesi Yayınları, 2019. 
Muhammet Akif Tiyek

Bilgen, Hafize Vuslat. İbrahim Aczî Kendî́nin Rubâileri (İlk 180 Rubâi). Konya: Selçuk Üniversitesi, Sosyal Bilimler Enstitüsü, Yüksek Lisans Tezi, 2018.

Çelik, Ahmet. Osmanlı'dan Cumhuriyet'e Konya Öğretmenleri. Konya: Konya Belediyesi Kültür Yayınları 414, 2020.

Uz, Mehmet Ali. Konya Kültürüne Hizmet Edenler. Konya: Konya Büyükşehir Belediyesi Kültür Yayınları No 48, 2003.

\section{Sonuç}

İbrahim Aczî, hayatı boyunca eser telifini bırakmamış velut bir müelliftir. Aczî’nin Yusuf Ağa Kütüphanesinde yazma olarak bulunan 39 eseri tespit edilmiștir. Kaleme aldığı eserlerinde öncelikle kendi hayatı olmak üzere Türk şair ve âşıklarına değinmiş; Mevlânâ (öl. 672/1273) ve ona duyduğu muhabbetle Mevlânâ'nın hayatını ve Mesnevî́sini çalışma konusu seçmiş; İslam dininin inanç ve ibadet ilkeleri ile insanların kendisine ve ötekine yönelik haklarına dair bilgiler vermiş; Ebü'l-Alâ Maarrî (öl. 449/1057) gibi önemli isimlerin hayatlarına yer vermiștir. Buna ek olarak toplumun değer verdiği tasavvufî şahsiyetler, Arapça ve Farsça şiirler, âleme ve insana dair düşünceler, Mevlânâ'nın DîvânI Kebîr'inden seçmeler yapılarak yayınlanan esere yönelik eleștiriler, bazı hastalıklara iyi geldiği belirtilen dualar, Peygamber efendimizin ilim ve âlimle ilgili hadisleri, Fârâbî (öl. 339/950), Dede Ömer Rûmî (öl. 892/1487) gibi önemli şahısların biyografileri, devlet yönetimine ilişkin düşünceler eserlerinde yer alan diğer konulardan bazılarını teşkil etmektedir.

Aczî, eser telifinin yanı sıra hayatının son dönemlerinde özellikle gazete yazılarına yoğunlaşmış ve vefat edene dek bu çalışmalarına son vermemiştir. Aczî̀nin Anadolu, Işlk, Öz Demokrat Konya, Sabah, Yeni Konya ve Yeni Meram gazetelerinde yazıları tespit edilmiştir. En fazla Yeni Konya ve Yeni Meram gazetelerinde yazılar kaleme almıștır. Gazete yazılarında dinî-ahlâkî konular, Mevlânâ ve Mesnevî, çeşitli olay ya da durumlara ilişkin kaleme aldığı şiirler ve düşünceler, gezi notları, kişilere ve eserlerine yönelik eleştiriler, Konya'ya yönelik bilgiler ön plana çıkmaktadır. Folklor Postası ve Konya Halkevi Aylık Kültür Dergisi'nde yazıları tespit edilen Aczî, en fazla Konya Halkevi Aylık Kültür Dergisi'nde makaleler kaleme almış ve bu dergide halk şairlerinin hayatları ve şiirlerine yönelik çalışmalarını yoğunlaştırmıştır. Ayrıca Aczî, tefrika ve makalelerinin yanı sıra Fuzûlî (öl. 963/1556) ve Mesnevîhân Mahmud Dede (öl. 1011/1602) gibi önemli şairlerin eserlerini tercüme ve istinsah etmiştir.

Aczî ve hayatı ile ilgili yapılan çalışmalar genel itibariyle sayıca çok olarak ifade edilebilirse de nitelik yönünden söz konusu çalışmaların birbirinin tekrarından öteye geçemediği görülmektedir. Aczî̀nin hayatı ile ilgili çalıșmalardan bazıları daha Aczî hayatta iken kaleme alınmış; onun vefatıyla birlikte bu durumdan duyulan üzüntüyü dile getirmek amacıyla çeşitli gazetelerde yazılar yazılmıştır. Aczî'nin eserlerinden yalnızca Farsça rubâîleri çalışılmış; bunun dışındaki eserleri ile ilgili herhangi bir çalışma tespit edilememiştir.

Netice itibariyle bu bibliyografya çalışması ile özellikle onun eserlerine dair yüzeysel olarak tekrar edilegelen bilgiler net bir şekilde ortaya konulmuştur. Bu sayede kendisini kültürel değerleri koruma ve gelecek nesillere aktarma konusunda azami dikkat gösteren bir müellifin bıraktığı miras ilgililerin dikkatine sunulmuştur. 


\section{Kaynakça}

Aksoyak, İsmail Hakkı. “Taşrada Değerli Bir Kültür Adamı: İbrahim Aczî Kendi”. Prof. Dr. Mehmet Arslan'a Armağan. Editör H. İbrahim Delice vd. 199-204. Sivas: Cumhuriyet Üniversitesi Yayınları, 2019.

Ceylan, Serdar. "İbrahim Aczi Kendi (1883-1965)”, Merhaba Gazetesi Akademik Sayfalar Vefâtının 50. Yılında İbrahim Aczi Kendi (1883-1965) Özel Sayı 15/18 (Haziran 2015), 274-277.

Çelik, Ahmet. "Konya'da Okul Anıları-I İbrahim Aczi'nin Okul Anıları”. Merhaba Gazetesi Akademik Sayfalar Vefatının 50. Yılında İbrahim Aczi Kendi (1883-1965) Özel Sayı 15/18 (Haziran 2015), 277-288.

Çelik, Ahmet. Osmanlı'dan Cumhuriyet'e Konya Öğretmenleri. Konya: Konya Belediyesi Kültür Yayınları 414, 2020.

Dikilitaș, Yalçın. “íbrahim Aczi Kendi”. Anadolu Manșet Gazetesi Kültür\&Sanat (5 Ağustos 2004), 2.

Kendi, Ahmet Cenap. "Babam İbrahim Aczi Kendi”. Memleket Gazetesi (30 Mayıs 2018). https://www.memleket.com.tr/babam-ibrahim-Aczî-kendi-25755yy.htm

Kendi, Ahmet Cenap. “Ölümünün 10.cu Yllında Şair İbrahim Aczi Kendi”. Yeni Konya (9 Ağustos 1975), 2.

Kendi, Ahmet Cenap. "Ölümünün 15. Yılında İbrahim Aczi Kendi Şair ve Edip, Hayatı ve Eserleri". Yeni Konya (5 Haziran 1979), 2.

Kendi, İbrahim Aczî. “Avcıllk Âlemi”. Yeni Meram (14 Ağustos 1965), 3.

Kendi, İbrahim Aczî. Dìvān-ı 'Aczī. Konya: Yusuf Ağa Kütüphanesi, 42 Yu 10437, 1a-356b.

Kendi, İbrahim Aczî. Hayāl Bāhçesi ve Hayātım. Konya: Yusuf Ağa Kütüphanesi, 42 Yu 11761, 1932, 1. cilt.

Kendi, İbrahim Aczî. Hayāl Bāhçesi ve Hayātım. Konya: Yusuf Ağa Kütüphanesi, 42 Yu 11765, 1932, 2. cilt.

Kendi, İbrahim Aczî. Hayātım ve Hayāl Bāġçesi. Konya: Yusuf Ağa Kütüphanesi, $42 \mathrm{Yu}$ 10451/1, 1. cilt, 1a-400b.

Küçükbezirci, Seyit. “Unutulmayacak Konyalılar Konya'nın Basın, Sanat, Kültür Adamları". Yeni Meram (11 Mart 1982), 1, 5.

Öz Demokrat Konya. "Folklorcularımız İbrahim Aczi Kendi” (14 Mayıs 1958), 2.

Öztelli, Cahit. "Folklorcularımız: İbrahim Aczi Kendi”. Türk Folklor Araștırmaları Dergisi 5/104 (Mart 1958), 1658-1659.

Uyar, Veli Sabri. "Hattatlar Armağanı”. Konya Halkevi Aylık Kültür Dergisi/123-124 (OcakŞubat 1949), 27-33.

Uz, Mehmet Ali. Konya Kültürüne Hizmet Edenler. Konya: Konya Büyükşehir Belediyesi Kültür Yayınları 48, 2003. 